\title{
MOTHER'S PARENTING STYLE AND TELEVISION MEDIA ACCESS DETERMINING BULLYING BEHAVIOR ON ELEMENTARY SCHOOL CHILDREN
}

\author{
Nurul Fitri Annisa Rokoyah*), Dwi Hastuti \\ Departemen Ilmu Keluarga dan Konsumen, Fakultas Ekonomi Manusia, Institut Pertanian Bogor, \\ Bogor 16680, Indonesia \\ ")E-mail: nurulfitriannisa96@gmail.com
}

\begin{abstract}
The purpose of this study was to analyze the influence of maternal parenting style and television media access on bullying behavior of elementary school children. The population in this study were 289 of $5^{\text {th }}$ grade students in two sub-districts of Bogor with an age range of 10-12 years. The entire study sample consisted of 74 students selected using a simple random sampling technique. Data collection was using a questionnaire tool with selfreport techniques and in-depth interviews as additional data. Data were processed and analyzed using multiple linear regression tests on the SPSS program. The results showed that less than half of mothers tend to have authoritative parenting styles. Children's access to television media is classified as the high category, which can be seen from the length of duration and the high frequency of watching television and the type of content that children watch is exposed to violence and not suitable to their age. Besides, bullying behavior that most children do is verbal bullying. The analysis results found that the mother's authoritarian parenting style and the high access of children using television media had a significant positive effect on the bullying behavior of elementary school children.
\end{abstract}

Keywords: bullying behavior, elementary school children, mother's parenting style, television media access

\section{Gaya Pengasuhan Ibu dan Akses Media Televisi Menentukan Perilaku Bullying Siswa Sekolah Dasar}

\begin{abstract}
Abstrak
Tujuan dari penelitian ini adalah untuk menganalisis pengaruh gaya pengasuhan ibu dan akses media televisi terhadap perilaku bullying siswa sekolah dasar. Populasi dalam penelitian ini adalah 289 siswa kelas 5 SD yang berada di dua Kecamatan di Kota Bogor dengan rentang usia 10-12 tahun. Contoh terdiri dari 74 siswa yang dipilih menggunakan teknik simple random sampling. Pengumpulan data dilakukan menggunakan alat bantu kuesioner dengan teknik self-report serta wawancara mendalam sebagai data tambahan. Data diolah dan dianalisis menggunakan uji regresi linear berganda pada program SPSS. Hasil penelitian menunjukkan bahwa kurang dari separuh ibu cenderung memiliki gaya pengasuhan otoritatif. Akses anak pada media televisi tergolong kategori tinggi, yang dilihat dari lamanya durasi dan tingginya frekuensi menonton televisi serta jenis tontonan yang ditonton anak masih banyak yang mengandung kekerasan dan tidak sesuai dengan usianya. Selain itu, perilaku bullying yang paling banyak dilakukan anak adalah bullying verbal. Hasil uji analisis menemukan bahwa gaya pengasuhan otoriter ibu dan tingginya akses anak menggunakan media televisi berpengaruh positif signifikan terhadap perilaku bullying siswa sekolah dasar.
\end{abstract}

Kata kunci: akses media televisi, gaya pengasuhan ibu, perilaku bullying, siswa sekolah dasar

\section{INTRODUCTION}

Children are vulnerable to bullying problems. Bullying behavior involves physical and verbal violence that can be done directly or indirectly (Juvonen, Espinoza, \& Schacter, 2016). Someone who is a bullying agent usually misuses their power to commit acts of violence to others who consider weaker (Hertinjung, 2013). In addition to the imbalance of power, bullying behavior according to Olweus (1994) is also characterized by the deliberate intention of the perpetrators to take aggressive actions to repeatedly hurt others.

Bullying behavior can occur at all ages, especially on school-age children. Khamis (2015) found that as many as 53,4 percent of school-age children in Beirut are reportedly involved in bullying cases. Bullying cases in Indonesia often occur in educational institutions (Septiyuni, Budimansyah, \& Wilodati, 2015). Based on data from Komisi Perlindungan Anak Indonesia (2017), from 
2011 to September 2017, there were 34 percent of 26 thousand cases of children received by KPAI related to violence against children. Then in 2016, there were 84 percent of school-aged children who were victims of bullying, and 70 percent of children had been bullied in schools. Data from KPAI (2017) also shows that West Java Province and DKI Jakarta Province are the two provinces in Indonesia with the most cases of bullying. Bogor is one of the regions in West Java Province that is prone to bullying cases. Arifinda and Hastuti (2016) found that as many as 93,33 percent of elementary school children have conducted verbal bullying at school. This indicates that elementary school children are vulnerable to becoming victims or perpetrators of bullying in schools so children need a safety family and school environment.

Elementary school children are included in the phase of the transition period of childhood to adolescence when children begin to look up to a variety of role models in the formation of their identity (Anwas, 2010). Family environment becomes one of the places where individuals grow and influence the formation of a child's personality. In a family environment, interactions between children and parents occur through parenting style (Pratama, Krisnatuti, \& Hastuti, 2014). Childcare is a process of interaction that occurs between parents and children to improve physical, mental and social development (Rakhmawati, 2015). Authoritative parenting style is seen as the best parenting style that can be applied by parents because it combines warmth, democracy, authority and openness to children (Coplan et al., 2002). Authoritarian parenting style emphasizes the importance of obedience and openness is frowned upon. Parents demand that children always obey the wishes of parents so that they have a negative impact on children's psychological development (Rakhmawati, 2015). Children become accustomed to behaving rudely both in home and social environments. The use of authoritarian parenting will encourage children to becoming bullying agents (Pratama, Krisnatuti, \& Hastuti, 2014). Parents who tend not to care and refuse the presence of their children can also cause children to not have competence in school and even engage in acts of violence in school (Benitez \& Justicia, 2006).

The development of information flows will affect the family, school and community environment (Anwas, 2010). One of the electronic media that is very well known by children is television. According to Badan
Pusat Statistik (2015), as many as 91,47 percent of Indonesia's population aged 10 years and over prefer watching television. Children and adolescents are more often exposed to violence from television shows than through mass media and other electronic media (Benitez \& Justicia, 2006). The results of the study by Stavrinides et al., (2013) and Astuti (2013) also showed that the higher exposure to violence that children get from television shows, the higher the potential for children to behave aggressively, one of which is bullying. The development of information media such as television has a positive impact if it is wisely used, one of which is to develop children's creativity and intelligence (Astiti, Hadi, \& Julia 2013). Parents are obliged to set a time limit for children to access television media and choose television shows that are child-friendly as an effort to minimize the negative impact of television shows on children's development (Ameliola \& Nugraha, 2013). If parents are lacking in providing supervision to children, they tend to choose their shows on television media as a medium of socialization (Stavrinides et al., 2013). Based on the explanation above, this is what underlies the research on how much influence the mother's parenting style and television media access on children. Specifically, this study aimed to: 1) identified parenting styles, television media access, and bullying behavior of elementary school children; and 2) analyze the influence of mother's parenting style and television media access on bullying behavior of elementary school children.

\section{METHODS}

The design of this study is cross-sectional with survey methods. The research location determined by purposive sampling, ie in two public elementary schools located in the district of South Bogor and West Bogor subdistrict, Bogor City. The school site selection recommended by Dinas Pendidikan Bogor. The research time included data collection, data processing, and report writing carried out from April to May 2018. The population of this study was all $5^{\text {th }}$ grade students in two selected schools. Samples in this study were 5th grade students and mothers as primary caregivers. The number of samples in this study was 74 students in 5th grade, with 42 male students and 32 female students aged 10 to 12 years. The sampling is done using a simple random sampling technique and is calculated using the Slovin formula $(e=10,0 \%)$. Then from the number of samples, 20 of them were selected to be interviewed in depth as supporting data. 
The types of data in this study include primary data and secondary data. Primary data is obtained by filling in the self-report using the help of a questionnaire that has been tested for reliability and validity, including: 1) child characteristics; 2) family characteristics; 3) mother's parenting style; 4) access to television media; and 5) bullying behavior of elementary school students, while secondary data is in the form of data on the number of students obtained from school. Characteristics of children consist of age, gender, and birth order. Family characteristics consisted of mother's age, mother's last education, mother's employment status, family per capita income, and family size. Age of mothers is categorized by age group according to Hurlock (1980), namely: 1) early adult (18-40 years); 2) middle adulthood (41-60 years); and 3 ) advanced adults (> 60 years). Family per capita income is measured based on total family income divided by family size and classified into poor and non-poor status based on the 2015 Bogor City Poverty Line (Bogor City BPS in Figures, 2017). Family size is grouped according to BKKBN (2005), namely: 1) small (4 people); 2) medium (5-7 people); and 3 ) large ( $\geq 8$ people).

The maternal parenting style variable was the most prominent and dominant way of interaction between mother and child in a family. Mother's parenting style instruments were adapted from Kimble (2014) and Latifah (2016) which included four dimensions: 1) authoritative consisting of 15 items of questions; 2) authoritarian consists of 14 question items; 3) permissive consists of 8 question items; and 4) neglect consists of 7 question items. The Cronbach's alpha value for the authoritative dimension is 0,884 , for the authoritarian dimension is 0,729 , for the permissive dimension is 0,735 , and for the neglect dimension is 0,881 . Television media access variables were all television media use activities carried out by children. The instrument for accessing television media was adapted from Rasalwati (2012), Arifinda and Hastuti (2016) and Suherman (2015) which included the habits of children watching television, television content preferences that were not suitable for children's age, and parental regulations related to television access to children consisting from 33 open question items and dimensions of television viewing duration consisting of 1 open question and 3 closed questions. The value of Cronbach's alpha for television media access is 0,618 . Measurement of maternal parenting style variables and access to television media used a Likert scale 1 (strongly disagree) to 4 (strongly agree). The variable of bullying behavior was an aggressive behavior and intimidation that is carried out repeatedly with hurt intentions. Bullying behavior instruments adapted from Karina, Hastuti, and Alfiasari (2013) consisted of 21 items of questions, including dimensions of physical, verbal, and indirect bullying behavior. Cronbach's alpha value for bullying behavior is 0,886 . Measurement of bullying behavior variables uses a Likert scale of 1 (never) to 4 (always).

Data is processed and analyzed using Microsoft Excel and the Statistical Program for Social Sciences (SPSS). Assessment of the research variables was carried out by a scoring system. The total score obtained is then changed in the form of an index to meet the requirements of statistical tests. Then these values are categorized using the index score cut-off point: 1) Low: <index average, 2) Height: $\geq$ index average. Open question questionnaires are used as additional data. Furthermore, the data were analyzed by using descriptive and inferential statistics. Descriptive analysis such as number, percentage, mean value, standard deviation, minimum value and maximal value is done to identify mother's parenting style, television media access and bullying behavior of elementary school children. Inference analysis used is multiple linear regression test to analyze the factors that influence bullying behavior of elementary school children.

\section{RESULTS}

\section{Children and Family Characteristics}

The results showed that most children $(78,4 \%)$ were 11 years old, with an age range of 10-12 years. Based on gender, the number of male students was more than female students, namely 42 boys and 32 girls. Less than half of the children $(45,9 \%)$ ranked the last birth (youngest) in their family. More than half of mothers $(51,4 \%)$ were in the early adult age group. The average age of the mother was 40,81 years, the youngest was 30 years and the oldest was 53 years. Mother's education duration ranges from 6-20 years. 


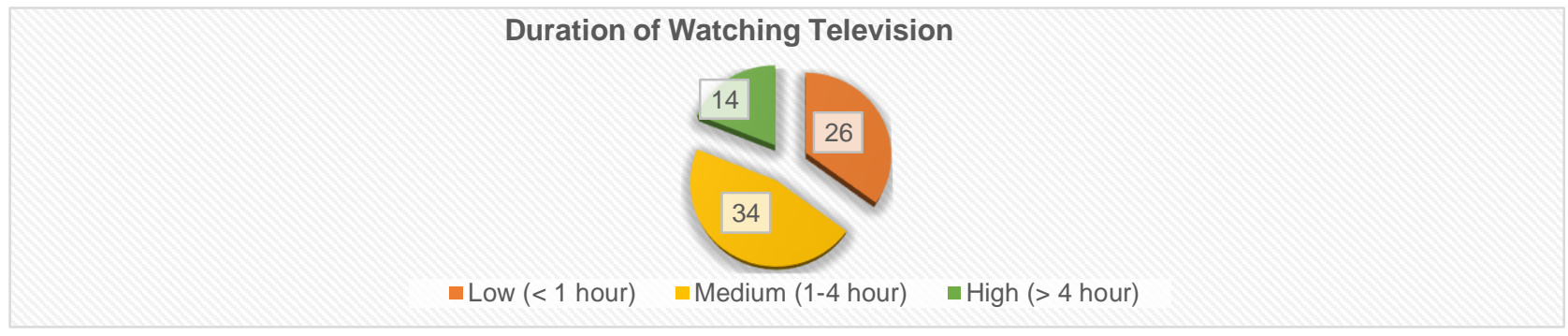

Figure 1 Distribution of children based on the duration of watching television

The most recent education for most mothers was graduating from high school $(62,2 \%)$. The average length of the mother's education was 12,97 years. Based on employment status, most of the mothers of children $(64,9 \%)$ did not work. The average family income per capita example was Rp1.590.608,00 and almost all families $(97,3 \%)$ were in the not poor category. The results showed that more than half of children $(51,3 \%)$ were in the small family category.

\section{Mother's Parenting Style}

Parenting style is divided into four typologies, namely authoritative, authoritarian, permissive, and uninvolved parenting style based on dimensions of responsiveness and demandingness. According to Baumrind, the dimension of demandingness refers to the demands of parents for children, high control and discipline, while the dimension of responsiveness refers to the support of warmth from parents towards children (Spera, 2005).

Table 1 shows that the parenting style carried out at home based on the perception of the mother who is considered as the primary caregiver of the child at home. Based on the index average, the authoritative parenting style has the highest average score among the other dimensions of 79,0 and 44,6 percent of sample mothers have a tendency to authoritative parenting style compared to other parenting styles.

Table 1 Distribution and descriptive analyesis of the mother's parenting style

\begin{tabular}{|c|c|c|c|c|}
\hline $\begin{array}{l}\text { The dimension } \\
\text { of } \quad \text { Parenting } \\
\text { Style }\end{array}$ & $\mathrm{n}$ & $\%$ & Ave & $\begin{array}{l}\text { Min- } \\
\text { Max }\end{array}$ \\
\hline Authoritati & 33 & 44,6 & 4 & \\
\hline Authorita & 13 & 17,6 & & \\
\hline Permissi & 10 & 13,5 & & $=, 5$ \\
\hline Jninvo & 18 & 24,3 & $16, \varsigma$ & 2,4 \\
\hline
\end{tabular}

\section{Children's Television Media Access}

Duration dan Intensity of Watching Television. The duration and intensity of watching television in this study is the time spent by children to watch television in one day, including the type of children's favorite shows and time spent by children to watch these favorite shows. Figure 1 shows that almost half of children $(46,0 \%)$ spent $1-4$ hours of television watching a day.

Based on the type of impressions that were liked, the children in this study liked watching some television shows that were packed in cartoons, sinetron, science and technology, reality shows, talk shows, and variety shows. However, some of the titles of television shows are considered not suitable for watching by children. This refers to the Broadcast Program Standard according to KPI (2012) that a television program must not violate a person's privacy rights, contain sexual content, physical and verbal violence, violate the values and norms of politeness and decency, and contain mystical and supernatural content. Table 2 shows the titles and descriptions of the most watched children and considered to contain violence.

The Children's Habit of Watching Television. The child's behavior in watching television and the tendency of children to watch television rather than do other activities such as learning, doing homework, and playing outside. Table 3 shows that more than half of children $(51,4 \%)$ have high television viewing habits with an average score of 45,01. Based on the distribution of answers, as many as 36,5 percent of samples watched television until late at night, as many as 28,4 percent of samples spent watching television until late eating, as many as 22,9 percent of samples forgot to do homework because of television, as much as 37,9 percent of samples chose watching television rather than playing, and as many as 54,0 percent of samples refuse to go outside. 
Table 2 Title and description of the program with violence

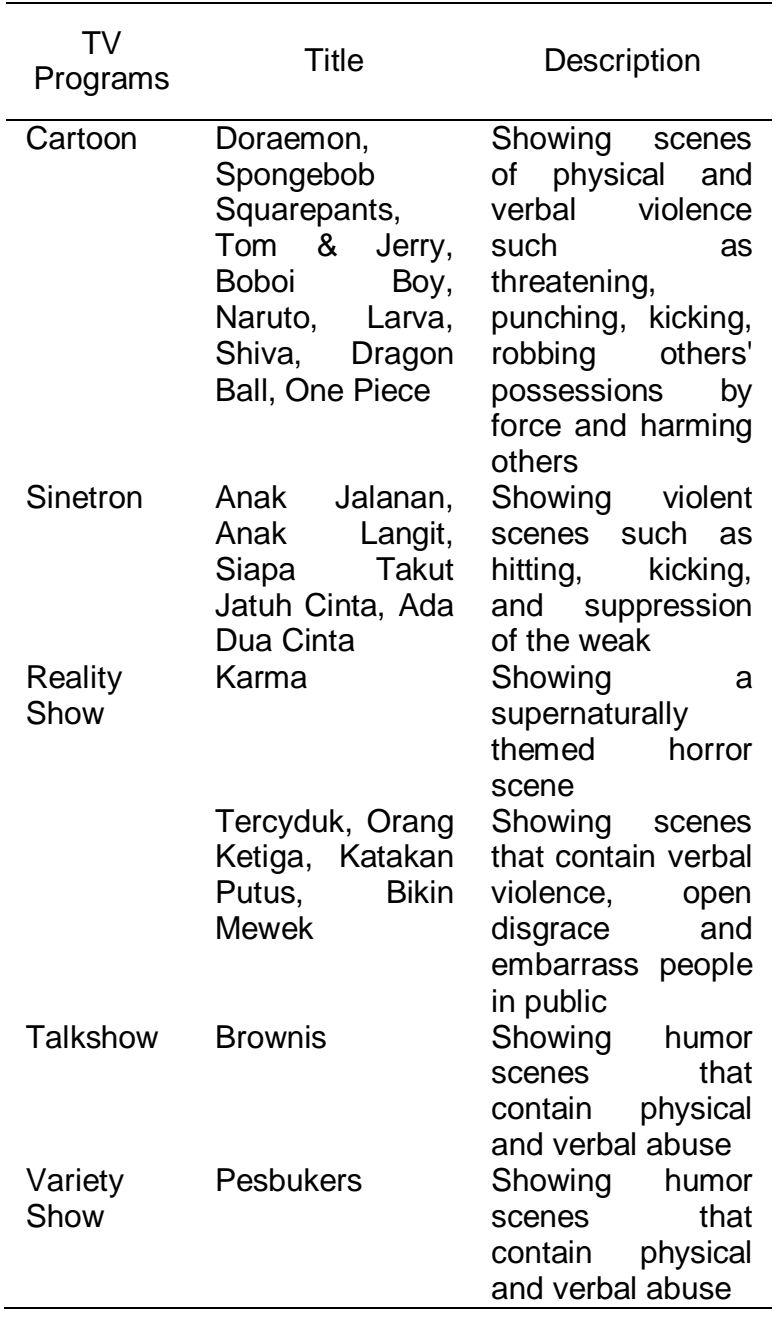

Figure 2 shows the intensity of children watching the most watched shows based on Table 2. Most of the children $(87,0 \%)$ watched these shows every day to the high category.
Preferences of TV Programs Which Inappropriate for Children. Preferences of TV programs which inappropriate for children is a child's preference in choosing to watch shows that contain violent scenes and are not suitable for the child's age. The results showed that more than half of children $(56,8 \%)$ had television content preferences that were violent and inappropriate for children, with an average value of 47,60 . Based on the distribution of answers, as many as 40,6 percent of children like watching cartoons that contain fighting scenes, as many as 54,1 percent of children like watching shows that are not suitable for them such as sinetron and as many as 33,8 percent of children see that fights are solving problems from sinetron or cartoon.

The Rule of Parents in order to Television Access. Parental regulation in this study is the regulation of parents at home related to television access according to children's perception. Table 3 shows that more than half of children $(56,8 \%)$ have perceptions of parental regulations regarding access to television in the high category. Based on the distribution of answers, as many as 54,1 percent of parents allow children to watch television after the child performs obligations such as studying and doing homework first, then as many as 54,1 percent of parents forbid children to turn on the television during study and worship, as much as 41,9 percent parents forbid children from watching television until late at night and as many as 41,9 percent of parents tell children to stop watching television if it's late at night.

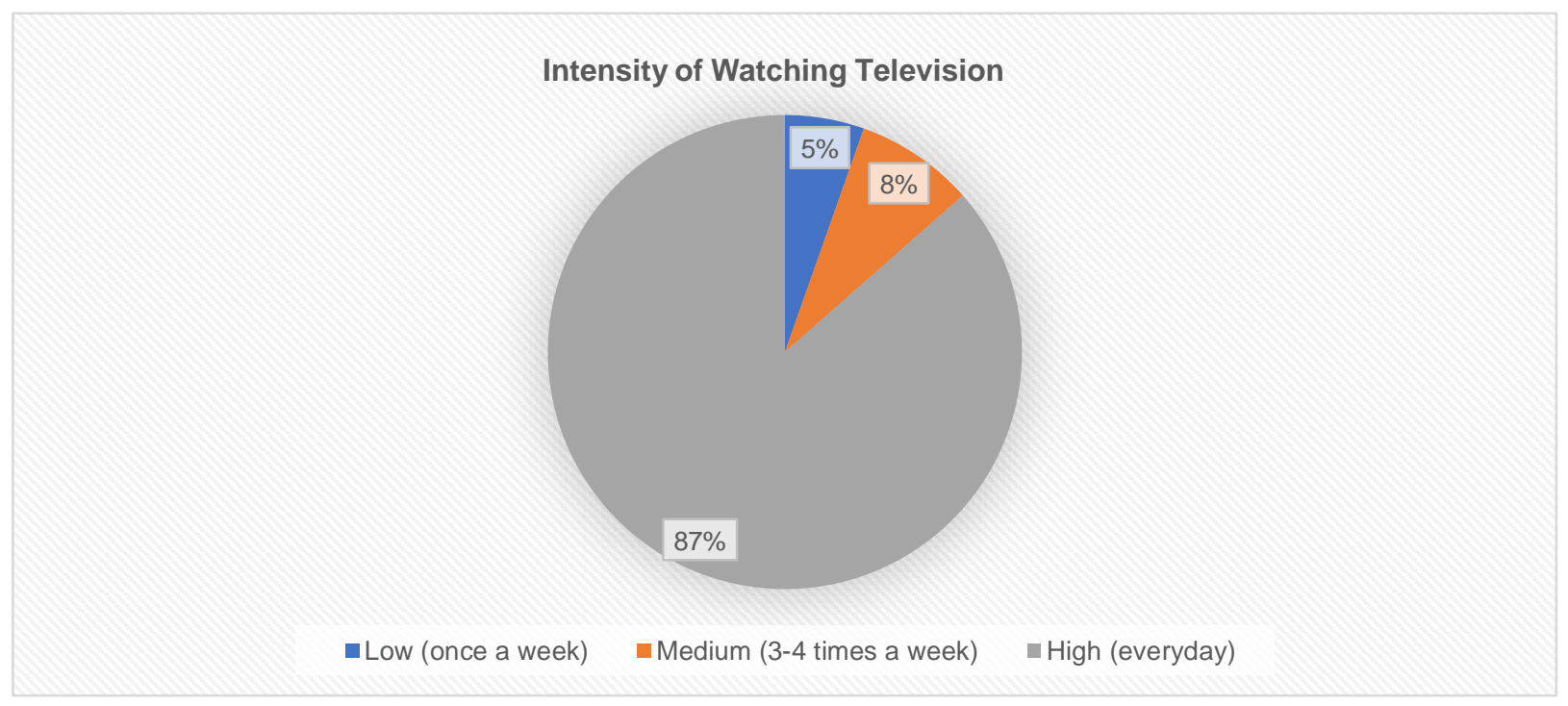

Figure 2 Distribution of children based on the intensity of watching television 
Table 3 Distribution of children based on television media access

\begin{tabular}{|c|c|c|c|c|}
\hline Variable & $\begin{array}{c}\text { Low } \\
\%\end{array}$ & $\begin{array}{l}\text { High } \\
\%\end{array}$ & $\begin{array}{c}\text { Average } \\
\pm S D\end{array}$ & $\begin{array}{l}\text { Min- } \\
\text { Max }\end{array}$ \\
\hline $\begin{array}{l}\text { The children's } \\
\text { habit of watching } \\
\text { television }\end{array}$ & 48,6 & 51,4 & $\begin{array}{c}45,01 \\
\pm 16,48\end{array}$ & $\begin{array}{l}10,3- \\
82,1\end{array}$ \\
\hline $\begin{array}{l}\text { Preferences of } \\
\text { TV programs } \\
\text { which } \\
\text { inappropriate for } \\
\text { children }\end{array}$ & 43,2 & 56,8 & $\begin{array}{c}47,69 \\
\pm 14,60\end{array}$ & $\begin{array}{l}14,8- \\
81,5\end{array}$ \\
\hline $\begin{array}{l}\text { The rule of } \\
\text { parents in order } \\
\text { to television } \\
\text { access }\end{array}$ & 43,2 & 56,8 & $\begin{array}{c}68,42 \\
\pm 15,08\end{array}$ & $\begin{array}{l}21,2- \\
93,9\end{array}$ \\
\hline
\end{tabular}

\section{Children's Bullying Behavior}

Bullying behavior in this study is divided into three categories, namely 1) physical bullying which includes the behavior of pushing, hitting, taking and/or hiding goods; 2) verbal bullying which includes calling behavior with a rough nickname, mocking, teasing, threatening; and 3) indirect relational or bullying bullying which includes the behavior of isolating or avoiding, making and/or disseminating slander or gossip (Hertinjung, 2015). Based on the index scores obtained, as many as 64,9 percent of children did physical bullying in the low category with an average index value of 14,48 . As many as 55,4 percent of children did verbal bullying in the low category with an average index value of 21,94 . As many as 55,4 percent of children do relational bullying in the low category with an average index value of 16,60 .

Figure 3 shows the distribution of answers based on ever (sometimes, often or always) or never bullying, physically, verbally or relationally to friends in school. Overall, 97,3 percent of the sample has a tendency to be a bullying agent at school, which is to bully their friends. Then out of 97,3 percent, 77 percent of children have ever done the physical, verbal or relational bullying. Verbal bullying is the most commonly carried out behavior because as many as 94,6 percents of samples have ever conducted verbal bullying against their friends at school. Verbal bullying behavior such as mocking and giving nicknames is the most frequent bullying behavior in school (Khamis, 2015).

\section{Factors that Influence the Behavior of Bullying}

Table 4 shows the factors that influence children's bullying behavior. This multiple linear regression test, the dimensions of television media access are integrated as a whole so that the dimensions of parental regulations related to television media access in children are invaded in order to represent access to children's television media better. Family per capita income has a significant negative effect on children's bullying behavior, meaning that each increase in one unit of family income per capita will reduce children's bullying behavior by 0,250 points $(\beta=-0,250 ; p<0,1)$. Mother's authoritarian parenting style $(\beta=0,225 ; p<0,1)$ and television media access $(\beta=0,517 ; p$ $<0,05$ ) had a significant positive effect on children's bullying behavior. This shows that each increase in one unit of mother's authoritarian parenting style will increase children's bullying behavior by 0,225 points and each increase in one unit of television media access will increase children's bullying behavior by 0,517 points. This model can explain the effect of bullying behavior by 25,60 percent, while the remaining 74,40 percent is influenced by other variables not examined in this study.

\section{DISCUSSION}

Respondents in this study were in the age range of 10-12 years including the final childhood phase and were a transition period from children to adolescents. In this phase, child development is very vulnerable to being influenced by the surrounding environment. Children at this age, begin to learn about the world outside the family, try to fit into the expectations of others, compare their performance with their peers and find opportunities for success in school (Eccles, 1999). Child development at this age determines the quality of the child at a later age (Pratama, Krisnatuti, \& Hastuti, 2014). The family environment in this study focuses on the parenting style provided by mothers who are considered as the primary caregiver of children at home.

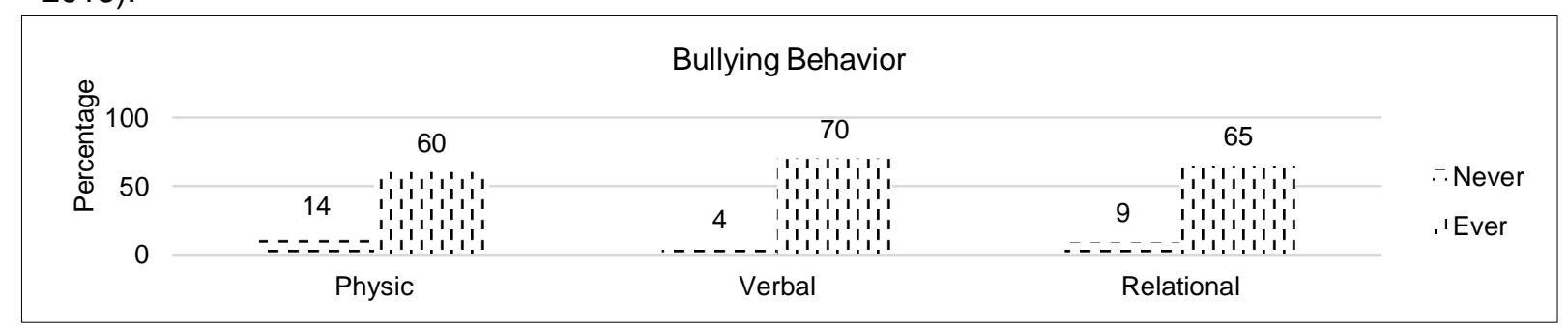

Figure 3 Distribution of children based on bullying behavior 
Table 4 Regresion test

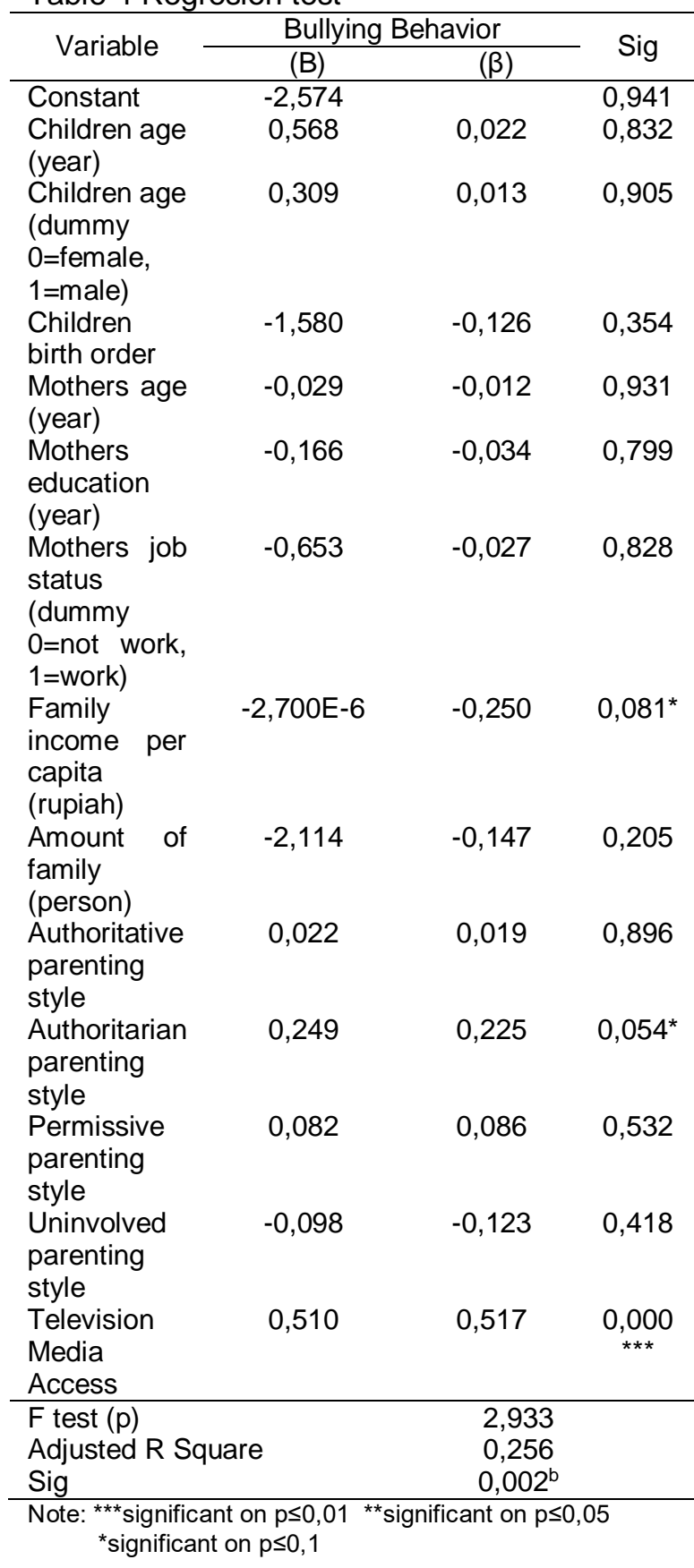

Mother's parenting style is divided into four typologies, namely the authoritative parenting style, authoritarian parenting style, permissive parenting style and neglect parenting style. The results showed that less than half of mothers tended to apply authoritative parenting styles. Based on the results of in-depth interviews, some mothers of respondents said that they had rules regarding children's daily schedules based on the results of discussions with children, giving praise or reward if the child did good or achieved an achievement and would listen and empathize with the child's feelings.
In addition, the development of information and communication technology is also prone to influence the development of children's behavior. At this age stage, children also have a high sense of curiosity because they are in the industrial phase vs. inferiority according to Erickson (Eccles, 1999). Children can learn from anywhere, including electronic media such as television. Television media can have many positive effects, but can also have a negative impact on children if they are misused. Based on the results of the study, children's access to television is quite high. Children in this study have a duration of watching television every day is 1-4 hours a day. This is in line with the results of Arango et al. (2014) which shows that primary school students watch television more than 2 hours a day. The results of the study by Owens et al. (1999) also shows that the average duration of children watching television per day is for approximately 2-3 hours. Based on the results of in-depth interviews, most respondents only have one television set at home and watch television in the family room, and only one in four respondents have more than one television at home, so that children can easily watch any television shows at home every day. Pradekso's (2014) research also shows that families who have more than one television unit in the house will have an impact on the potential of children exposed to television programs will be more significant and more difficult to control the behavior of children in watching television.

Children also have high television viewing habits. Research by Dutra et al. (2014) also shows that children are accustomed to spending time watching television compared to physical activities outside the home. The preference of children in watching content containing violence also includes high categories. According to Lukmana (2011), television shows of violence can take the form of soap operas that display violence through fights, harsh words, criminal news shows that display abuse, violence, and so on. Some of the shows most watched by children in this study are shows that contain violence and are packed in cartoons, soap operas, reality shows and variety shows. Some respondents stated that the show was an interesting and exciting program to watch, and it was not uncommon for respondents to watch the program because of family members who also loved watching the show.

Access to television media on children is closely related to parental strategies in setting 
rules at home. Children have a perception that parental regulations regarding television media access are included in the high category. Efforts to regulate children's behavior in watching television in addition to regulations, also need an authority figure from parents to monitor and ensure that the regulation is implemented. In addition, children also need to understand the rules and understand their benefits so that they are willing to implement them (Pradekso, 2014). The existence of rules and supervision from parents is needed because in childhood this is the most effective time in shaping children's behavior (Aulina, 2013).

Bullying behavior is aggressive behavior that is carried out repeatedly with the aim of hurting someone as a victim (Medeiros et al., (2016). Bullying is one of the aggressive behaviors that arise due to the negative influence of television shows (Stavrinides et al., 2013), can also is the result of the adoption of authoritarian motherin-house care styles (Papanikolaou, Chatzikosma, \& Kleio, 2011). This study focuses on the tendency of children to be a bully, seen from ever or never have bullied their friends. Conducted in this study is verbal bullying, such as mocking parents 'names, mocking physical forms (short, pug, fat, etc.), and laughing at friends' mistakes. In line with the research of Papanikolaou, Chatzikosma, and Kleio (2011), Karina, Hastuti, and Alfiasari (2013), and Arifinda and Hastuti (2015) who state that verbal bullying is behavior the most widely practiced by students at the school. Verbal bullying behavior does not have a direct effect but can affect the psychological and emotional conditions felt by victims (Salleh \& Zainal, 2014).

Mother's authoritarian parenting style in this study can improve the bullying behavior of elementary school students. This is in line with the results of the Papanikolaou, Chatzikosma, and Kleio (2011) research which also states that mothers with an authoritarian parenting style shape bullying behavior in children. Physical punishment by the mother is more related to the emergence of bullying behavior in children, compared to if the punishment is given by the father (Zottis et al., 2013). The more strict and strict parents apply discipline to children, the higher the likelihood that children will become bullying agents. Authoritarian attitudes and violence from parents will make children's self-confidence decrease and make them aggressive (Dewi \& Susilawati, 2016). Forms of physical punishment such as hitting and cruel words from the mother are also related to the emergence of bullying behavior in children (Zottis et al., 2013). Based on the perspective of social learning, the aggressiveness of parents can make children behave aggressively as well as their peers, because they learn that the use of harsh words and violence is a way to interact (Gómez-Ortiz, Romera, \& Ortega-Ruiz, 2016).

Children access to television media that is high in this study can also improve bullying behavior. This is in line with the research of Arifinda and Hastuti (2016) who also found that access to children's television media had a significant positive effect on bullying behavior of elementary school students. Stavrinides et al. (2013) stated that children involved in bullying behavior are caused by what they see on television or they watch programs that contain violence because it is in accordance with aggressive behavior that has been embedded in them. Television shows watched by children will significantly affect children's behavior (Keating, 2011). The higher children's access to watching violent shows on television, the higher the tendency of children to behave aggressively, compared to children who are rarely exposed to violent shows from watching television (Lukmana, 2011).

Family per capita income in this study can reduce bullying behavior of elementary school students. This is in line with the results of research by Tirtayanti, Nurjannah, and Lusmilasari (2017) who found that parents with low socioeconomic conditions tended to be inconsistent in applying discipline to children. Parents with low socioeconomic conditions tend to be inconsistent in implementing discipline in children and the educational background of parents can also influence the mindset of parents in educating children. But in contrast to the results of Salleh and Zainal (2014) who did not find the socioeconomic status of the family influencing the bullying behavior of children, children with high socioeconomic status also had a tendency to become bullying agents. Even the results of Holt Kaufman, and Finkelhor (2009) found that children from low economic status tend to be victims of bullying. According to Hymel et al. (2009) children who come from high economic and social status bullying as a way to increase social strength and feel more powerful than their peers, while children who come from low economic and social status bullying as a way of diverting ridicule directed at them and to improve their social position so that they are equal to their peers. This is what underlies family income per capita can be one of the 
factors that influence bullying behavior in children, both as perpetrators and victims, although it cannot be said to have a direct effect because of many other factors that influence bullying behavior of elementary school students.

\section{CONCLUSION AND RECOMMENDATION}

The majority of 5 th grade students in Bogor did, at least once, physically, verbally and relationally bullying at school. The most common bullying behavior is verbal bullying. Bullying behavior is closely related to maternal parenting style and television media access to children. The results showed that less than half of mothers had authoritative parenting styles. The duration of the child watching television in this study was 1-4 hours every day. The types of shows that are often watched by children vary, but some of them contain violent scenes that are packed in cartoon films, soap operas, reality shows, talk shows, and variety shows. Children have a habit of watching television until late at night and prefer to watch television first than do other activities such as learning, doing homework, and playing. Children also tend to prefer watching cartoons that contain fighting scenes and soap operas that are not suitable for the child's age. Parents have special regulations regarding access to television media at home, such as television viewing schedules and restrictions on watching certain shows. Increasing the mother's authoritarian parenting style and increasing television media access in children will increase children's bullying behavior.

Based on research, researchers suggest parents should provide explanations and discuss with children about the positive and negative effects of various television shows. The application of authoritative parenting styles and parental supervision related to television media access is expected to minimize the emergence of aggressive behavior in children. The school should also be more severe in taking action regarding bullying that occurs between students. The government is also expected to be more selective in sorting out shows that are worth watching for children and making stricter policies in an effort to stop bullying in schools. In addition, for similar studies can be carried out in several elementary schools in Bogor to represent Bogor as a great city. Subsequent research can also examine more deeply about internal factors and environmental factors outside child's home which are thought to contribute to bullying behavior in children.

\section{REFERENCE}

Ameliola, S., Nugraha, H.D., (2013). Perkembangan media informasi dan teknologi terhadap anak dalam era globalisasi. Prosiding In International Conference On Indonesian Studies" Ethnicity And Globalization.

Anwas, O. M. (2010). Televisi mendidik karakter bangsa: harapan dan tantangan. Jurnal Pendidikan dan Kebudayaan, 16(9):256-266.

Arango, C. M., Páez, D. C., Lema, L., Sarmiento, O. L., \& Parra, D. C. (2014). Television viewing and its association with health-related quality of life in school-age children from Montería, Colombia. Journal of Exercise Science \& Fitness, 12(2), 68-72. doi: 10.1016/j.jesf.2014.07.002

Arifinda, N, A., \& Hastuti D. (2016). The influence of television access and impersonating violent contents to bullying behavior on elementary school children. Journal of Child Development Studies, 1(01), 1-12. E-ISSN: 24602310.

Astiti, D., Hadi, H., Julia, M. (2013). Pola menonton televisi sebagai faktor risiko obesitas pada anak di sekolah dasar Kota Yogyakarta dan Kabupaten Bantul. Jurnal Gizi dan Dietetik Indonesia (Indonesian Journal of Nutrition and Dietetics), 1(2):110-119.

Astuti, S. I. (2013). Patologi kekerasan dalam berita televisi: antara kontroversi dan regulasi. MIMBAR, Jurnal Sosial dan Pembangunan, 29(1), 41-48. ISSN: 0215-8175.

Aulina, C. N. (2013). Penanaman disiplin pada anak usia dini. PEDAGOGIA: Jurnal Pendidikan, 2(1), 36-49. doi: https://doi.org/10.21070/pedagogia.v2i1. 45.

Benitez, J, L., Justicia, F. (2006). Bullying: description and analysis of the phenomenon. Electronic Journal of Research in Educational Psychology, 4(2), 151-170. ISSN: 1696-2095.

[BKKBN]. Badan Koordinasi Keluarga Berencana Nasional. (2005). Data Besar Keluarga [internet]. Diambil dari www.bkkbn.go.id. [diunduh pada April 2018].

[BPS] Badan Pusat Statistik. (2015). Indikator Sosial Budaya (Persentase Penduduk 
Berumur 10 Tahun ke Atas yang Menonton Televisi, Mendengarkan Radio, dan Membaca Surat Kabar/Majalah. [internet]. Diambil dari www.bps.go.id. [diunduh pada Mei 2018].

[BPS] Badan Pusat Statistik. (2017). Kota Bogor dalam Angka 2017. Berita Resmi Statistik [internet]. Diambil dari http://www.bogorkota.bps.go.id. [diunduh pada April 2018].

Coplan, R. J., Hastings, P. D., Lagacé-Séguin, D. G., \& Moulton, C. E. (2002). Authoritative and authoritarian mothers' parenting goals, attributions, and emotions across different childrearing contexts. Parenting, 2(1), 1-26. doi: 10.1207/S15327922PAR0201_1.

Dewi, N. P. A. R., \& Susilawati, L. K. P. A. (2016). Hubungan antara kecenderungan pola asuh otoriter (authoritarian parenting style) dengan gejala perilaku agresif pada remaja. Jurnal Psikologi Udayana, 3(1), 108-116. ISSN: 2354-5607.

Dutra, G. F., Kaufmann, C. C., Pretto, A. D., \& Albernaz, E. P. (2015). Television viewing habits and their influence on physical activity and childhood overweight. Jornal de Pediatria (Versão em Português), 91(4), 346-351. doi: 10.1016/j.jped.2014.11.002.

Eccles, J. S. (1999). The development of children ages 6 to 14 . The future of children, 9(2):30-44.

Gómez-Ortiz, O., Romera, E. M., \& OrtegaRuiz, R. (2016). Parenting styles and bullying. The mediating role of parental psychological aggression and physical punishment. Child Abuse \& Neglect, 51, 132-143. doi: 10.1016/j.chiabu.2015.10.025.

Hertinjung, W. S. (2013). Bentuk-bentuk perilaku bullying di sekolah dasar. Jurnal Psikologi, 7:450-458.

Hurlock, E, B. (1980). Psikologi Perkembangan. Istiwidayanti, Soedjarwo, penerjemah; Sijabat RM, editor. Jakarta (ID): Erlangga. Terjemahan dari: Development Psychology. Ed ke-5.

Holt, M, K., Kaufman, K, G., Finkelhor, D. (2008). Parent/child concordance about bullying involvement and family characteristics related to bullying and peer victimization. Journal of School
Violence, $8(1), \quad 42-63 . \quad$ doi: 10.1080/15388220802067813.

Hymel, S., Swearer, S., Gillete, P., \& Daniels, D. (2009). Bullying at School and Online. Education.com

Juvonen, J., Espinoza, G., \& Schacter, H, L. (2016). Bullying. Encyclopedia of Mental Health, 1, 216-221. doi: 10.1016/B9780-12-397045-9.00231-7.

Karina, K., Hastuti, D., \& Alfiasari, A. (2013). Perilaku bullying dan karakter remaja serta kaitannya dengan karakteristik keluarga dan peer group. Jurnal IImu Keluarga \& Konsumen, 6(1), 20-29. ISSN: 1907-6037.

Keating, S. (2011). A study on the impact of electronic media, particularly television and computer consoles, upon traditional childhood play and certain aspects of psychosocial development amongst children. International Journal for CrossDisciplinary Subjects in Education, 2(1), 294-303. 10.20533/ijicr.2042.6364.2011.0042.

Khamis, V. (2015). Bullying among school-age children in the greater Beirut area: Risk and protective factors. Child abuse \& neglect, 39, 137-146. doi: 10.1016/j.chiabu.2014.08.005.

Kimble, A, B. (2014). The parenting styles and dimensions questionnaire: a reconceptualization and validation (Thesis). Oklahoma State University, Oklahoma, United States of America (USA)

[KPAI]. Komisi Perlindungan Anak Indonesia. (2017). Catatan akhir tahun-KPAI meneropong persoalan anak. Diambil dari www.kpai.go.id. [diunduh pada Mei 2018].

[KPI]. Komisi Penyiaran Indonesia. (2012). Pedoman perilaku penyiaran (P3) dan standar program siaran (SPS). Diambil dari www.kpi.go.id. [diunduh pada Mei 2018].

Latifah, E, W. (2016). Pengaruh gaya pengasuhan ibu dan nenek terhadap perkembangan kemandirian dan kognitif anak usia prasekolah (Thesis). Institut Pertanian Bogor, Bogor, Indonesia

Lukmana, I. (2011). Hubungan Frekuensi Menonton Tayangan Kekerasan di Televisi Terhadap Perilaku Agresif pada Anak Kelas IV di SD Glagahombo 1 
Tempel (Disertasi). STIKES Aisyiyah, Yogyakarta, Indonesia

Medeiros, W., Torro-Alves, N., Malloy-Diniz, L. F., \& Minervino, C. M. (2016). Executive functions in children who experience bullying situations. Frontiers in psychology, 7(1197), 1-9. doi: 10.3389/fpsyg.2016.01197.

Olweus, D. (1994). Bully/victim problems among schoolchildren: Basic facts and effects of a school based intervention program. Child Physical Psychist, 55(7):1171-1190.

Owens, J., Maxim, R., McGuinn, M., Nobile, C., Msall, M., \& Alario, A. (1999). Television-viewing habits and sleep disturbance in school children. Pediatrics, 104(3):1-8.

Papanikolaou, M., Chatzikosma, T., \& Kleio, K. (2011). Bullying at school: the role of family. Procedia-Social and Behavioral Sciences, 29, 433-442. doi: 10.1016/j.sbspro.2011.11.260.

Pradekso, T. (2014). Pengaruh kampanye pendidikan media pada perilaku anak dalam menonton televisi. INTERAKSI: Jurnal Ilmu Komunikasi, 3(1):1-14.

Pratama, A, A. (2014). Pengaruh gaya pengasuhan ibu, kekerasan di rumah dan perilaku bullying sekolah terhadap self-esteem anak sekolah dasar. (Thesis). Institut Pertanian Bogor, Bogor, Indonesia

Pratama, A, A., Krisnatuti, D., \& Hastuti, D. (2014). Gaya pengasuhan otoriter dan perilaku bullying di sekolah menurunkan self-esteem anak usia sekolah. Jurnal IImu Keluarga dan Konsumen. 7(2), 7582. ISSN: 1907-6037.

Rakhmawati, I. (2015). Peran keluarga dalam pengasuhan anak. Bimbingan Konseling Islam, 6, 1-18. doi: http://dx.doi.org/10.21043/kr.v6i1.1037.

Rasalwati, U, H. (2012). Ekologi pengasuhan anak: persepsi remaja terhadap gaya pengasuhan, paparan media, dan perkembangan psikososial remaja di Kota Bandung. (Disertasi). Institut Pertanian Bogor, Bogor, Indonesia

Salleh, N. M., \& Zainal, K. (2014). Bullying among secondary school students in Malaysia: a case study. International Education Studies, 7(13), 184-191. doi: 10.5539/ies.v7n13p184.

Septiyuni, D. A., Budimansyah, D., \& Wilodati, W. (2015). Pengaruh kelompok teman sebaya (peer group) terhadap perilaku bullying siswa sekolah. SOSIETAS, 5(1):1-4.

Spera, C. (2005). A review of the relationship among parenting practices, parenting styles, and adolescent school achievement. Educational psychology review, 17(2), 125-146. doi: 10.1007/s10648-005-3950-1.

Suherman. (2015). Pengaruh antara intensitas menonton tayangan televisi dan kendali orang tua dalam menonton tayangan televisi, terhadap perilaku anak usia dini di TK Islam Syaichona Cholil Balikpapan. (Thesis). UIN Sunan Kalijaga, Yogyakarta, Indonesia

Stavrinides, P., Tsivitanou, A., Nikiforou, M., Hawa, V., \& Tsolia, V. (2013). Longitudinal associations between bullying and children's preference for television violence. International journal of criminology and sociology, 2, 72-78. E-ISSN: 1929-4409/13.

Tirtayanti, S., Nurjannah, I., \& Lusmilasari, L. (2017). Association between emotional development and bullying behavior in children at the elementary school no 7 , Banyuasin, Prajin, Palembang. Belitung Nursing Journal, 3(5), 585-594. ISSN: 2477-4073.

Zottis, G. A., Salum, G. A., Isolan, L. R., Manfro, G. G., \& Heldt, E. (2014). Associations between child disciplinary practices and bullying behavior in adolescents. Journal de Pediatria, 90(4), 408-414. 